\title{
Relevancy Analysis of UHVDC Power Transmission and Provincial Power Source Construction
}

\author{
Guangzeng Sun ${ }^{1, *}$, Linlin $\mathrm{Yu}^{2}$, Yongmin $\mathrm{Liu}^{2}$, Gengyin $\mathrm{Li}^{1}$, Jinghui Huang ${ }^{2}$ and Jing Wang ${ }^{1}$ \\ ${ }^{1}$ North China Electric Power University, Beijing, China \\ ${ }^{2}$ State Grid Henan Economic Research Institute, Zhengzhou, Henan, China \\ ${ }^{*}$ Corresponding author
}

\begin{abstract}
The rapid development of UHVDC power transmission makes the proportion of external power accepted by provinces increase significantly. This paper aims at analyzing the relevancy of UHVDC power transmission and provincial power source construction from two aspects of reliability and environmental protection, as well as finding the relevancy characteristics. Firstly, we establish the evaluation index system for power source construction and UHVDC power transmission. Secondly, we establish the correlation model based on the grey correlation analysis algorithm, and solve models by using Matlab software programming. Last, we take a province and an $\pm 800 \mathrm{kV}$ UHVDC power transmission engineering for example to conduct a case study. According to evaluation index system and data mining, the research calculates grey correlation value of the UHVDC power transmission and power source construction system, and qualitatively and quantitatively analyses the relevancy characteristics between the above two systems. The result reveals the inner relevancy and dominant factors between the $\pm 800 \mathrm{kV}$ UHVDC power transmission and provincial power source construction.
\end{abstract}

Keywords-UHVDC; power source construction; evaluation index; relevancy analysis

\section{INTRODUCTION}

The UHVDC power transmission in China is developing rapidly and has a significant impact on power construction. The level of power construction also affects the safety and reliability of the UHVDC power transmission system. Along with the process of electric power system reform and the implementation of the national energy strategy, the effect of reliable power supply and environmental protection on power generation, power source construction and even power layout will be more and more highlighted. In this context, in order to coordinate UHVDC power transmission and power source construction in the province, the paper establishes the correlation model based on grey correlation analysis and solves models by using Matlab software programming. The research content can provide the basis and foundation of internal power dissolution together with external power, power source planning and construction in the province.

There have been studies conducted on power sources construction over many years. The most important thing of traditional power planning is constructing the objective function and constraint condition [1]. When the objective function and constraint condition was constructed, authors use different artificial intelligent algorithms to solve this nonlinear programming problem in [2-5]. The research on reliability analysis of UHVDC transmission systems also has been going on for a long time. Markov theory has been put forward to calculate the reliability of UHVDC transmission system in [6], and the paper[7] presents another method called state space method to calculate it. The evaluation indexes of UHVDC transmission system was discussed in [8-10]. The effects of different components on the overall reliability of UHVDC system are investigated in [11]. However, there are very few researchers pay their attention to combine the power sources construction with UHVDC transmission system, and analyze the relevancy between them. When a province has more and more landing point of UHVDC transmission project, the power sources construction must be influenced.

In this paper, the evaluation index systems of UHVDC transmission reliability and power sources construction were established in section II. The evaluation index system selected the most representative indexes to reflect the safety, adequacy and environment of power sources construction and UHVDC transmission. According to the grey correlation analysis algorithm, the correlation model was established in section III. The model comprised 6 parts: form characteristic sequence, make indexes being dimensionless, calculate the maximum and minimum range, calculate grey relational coefficient, calculate grey relational degree and classify grey relational degree. A province which has landing point of $\pm 800 \mathrm{kV}$ UHVDC transmission engineering was taken for example in section IV.

\section{ESTABLISHMENT OF EVALUATION INDEX SYSTEM}

\section{A. The Evaluation Index System of Power Sources} Construction

The evaluation index system collectively contained 16 indexes, which were divided into three levels (Table 1). Firstlevel index is system level index, it reflects the whole situation of power sources construction. This index consists of three second-level indications: safety index, adequacy index and environment index. Further more, safety index consists of 5 third-level indexes: $\mathrm{N}-1$ pass rate, $\mathrm{N}-2$ pass rate, short-circuit current, the percentage of transmission capacity from other provinces and reactive power compensation. Adequacy index consists of 7 third-level indexes: installed capacity, maximum load, the percentage of conventional hydropower, the percentage of pumped-storage power, the percentage of wind power, the percentage of thermal power and the percentage of Photovoltaic power. Environment index consists of 4 thirdlevel indexes: the percentage of renewable energy, the weight 
of saving standard coal, $\mathrm{CO}_{2}$ emission reduction and $\mathrm{SO}_{2}$ emission reduction.

TABLE I. THE INDEX SYSTEM OF POWER SOURCES CONSTRUCTION

\begin{tabular}{|c|c|c|}
\hline First-level Index & Second-level Index & Third-level Index \\
\hline \multirow{16}{*}{$\begin{array}{l}\text { The Evaluation } \\
\text { Index of Power } \\
\text { Sources } \\
\text { Construction }\end{array}$} & \multirow{5}{*}{ Safety Index } & $\mathrm{N}-1$ pass rate \\
\hline & & $\mathrm{N}-2$ pass rate \\
\hline & & Short-circuit Current \\
\hline & & $\begin{array}{l}\text { The Percentage of } \\
\text { Transmission Capacity } \\
\text { from other Provinces }\end{array}$ \\
\hline & & $\begin{array}{l}\text { Reactive Power } \\
\text { Compensation }\end{array}$ \\
\hline & \multirow{7}{*}{ Adequacy Index } & Installed Capacity \\
\hline & & Maximum Load \\
\hline & & $\begin{array}{c}\text { The Percentage of } \\
\text { Conventional } \\
\text { Hydropower }\end{array}$ \\
\hline & & $\begin{array}{c}\text { The Percentage of } \\
\text { Pumped-storage Power }\end{array}$ \\
\hline & & $\begin{array}{l}\text { The Percentage of } \\
\text { Thermal Power }\end{array}$ \\
\hline & & $\begin{array}{c}\text { The Percentage of Wind } \\
\text { Power }\end{array}$ \\
\hline & & $\begin{array}{l}\text { The Percentage of } \\
\text { Photovoltaic Power }\end{array}$ \\
\hline & \multirow{4}{*}{ Environment Index } & $\begin{array}{l}\text { The Percentage of } \\
\text { Renewable Energy }\end{array}$ \\
\hline & & $\begin{array}{c}\text { The Weight of Saving } \\
\text { Standard Coal }\end{array}$ \\
\hline & & $\begin{array}{l}\mathrm{CO}_{2} \text { Emission } \\
\text { Reduction }\end{array}$ \\
\hline & & $\begin{array}{c}\mathrm{SO}_{2} \text { Emission } \\
\text { Reduction }\end{array}$ \\
\hline
\end{tabular}

B. The Evaluation Index System of UHVDC Transmission Reliability

TABLE II. THE EVALUATION INDEX SYSTEM OF UHVDC TRANSMISSION RELIABILITY

\begin{tabular}{|c|c|}
\hline \multirow{4}{*}{$\begin{array}{c}\text { The Evaluation } \\
\text { Index System of } \\
\text { UHVDC } \\
\text { Transmission } \\
\text { Reliability }\end{array}$} & Forced Energy Unavailability \\
\cline { 2 - 2 } & Scheduled Energy Unavailability \\
\cline { 2 - 2 } & Bonopole Forced Outage Times \\
\cline { 2 - 2 } & Bipolar Forced Outage Times \\
\hline
\end{tabular}

The evaluation index system of UHVDC transmission reliability consists of 5 indexes: energy availability, forced energy unavailability, scheduled energy unavailability, monopole forced outage times, bipolar forced outage times(Table 2).

\section{Grey Correlation Model of PoWer Sources CONSTRUCTION AND UHVDC TRANSMISSION RELIABILITY}

Before you begin to format your paper, first write and save the content as a separate text file. Keep your text and graphic files separate until after the text has been formatted and styled. Do not use hard tabs, and limit use of hard returns to only one return at the end of a paragraph. Do not add any kind of pagination anywhere in the paper. Do not number text headsthe template will do that for you. The correlation model based on the grey correlation analysis algorithm was established to analysis the correlation between power sources construction and UHVDC transmission reliability.

\section{A. Characteristic Sequence Forming}

Suppose there are $\mathrm{n}$ indexes, and $\mathrm{m}$ characteristic data of each index. As in (1), a $\mathrm{n} * \mathrm{~m}$ characteristic sequence is formed to reflect the behavior characteristics of power sources construction system and UHVDC transmission reliability system. Two sequences are 16 indexes of power sources construction $\left(X_{i}(i=1,2, \ldots, 16)\right)$ and 5 indexes of UHVDC transmission reliability $\left(Y_{i}(j=1,2,3,4,5)\right)$. The sequence of power sources construction was selected as reference sequence.

$$
\left(X_{0}, X_{1}, X_{2}, \ldots, X_{m}\right)=\left(\begin{array}{cccc}
x_{0}(1) & x_{1}(1) & \ldots & x_{m}(1) \\
x_{0}(2) & x_{1}(2) & \ldots & x_{m}(2) \\
\ldots & \ldots & \ldots & \ldots \\
x_{0}(n) & x_{1}(n) & \ldots & x_{m}(n)
\end{array}\right)(1)
$$

\section{B. Make Indexes Being Dimensionless}

The dimension of two sequences ( $\mathrm{Xi}$ and $\mathrm{Yj}$ ) were eliminated by equalization operator. For all the data of original data sequence are removed with mean value of each sequence to form a new sequence which dimension is 1 , as in (2).

$$
X_{i}^{\prime}=\frac{\bar{X}}{X_{i}}, \quad Y_{j}^{\prime}=\frac{\bar{Y}}{Y_{j}}
$$

where, $\bar{X}$ is the mean value of $x_{i}(k)$;

$$
\bar{Y} \text { is the mean value of } y_{j}(k) \text {. }
$$

\section{Calculate the Range}

The difference sequences $\left(\Delta_{i}(k)\right)$ is the absolute difference between dimensionless sequences $\left(X_{i}^{\prime}(k)\right.$ and $\left.Y_{j}^{\prime}(k)\right)$ and the corresponding element of reference sequence $\left(X_{0}^{\prime}(k)\right.$ ), as in (3). The maximum value of all elements of difference sequence is the maximum range, as in (4). The minimum value of all elements of difference sequence is the minimum range, as in (5). 


$$
\begin{gathered}
\Delta_{i}(k)=\left|x_{0}^{\prime}(k)-x_{i}^{\prime}(k)\right| \\
M X=\max _{i} \max _{k}\left|x_{i}^{\prime}(k)-y_{j}^{\prime}(k)\right| \\
M N=\min _{i} \min _{k}\left|x_{i}^{\prime}(k)-y_{j}^{\prime}(k)\right|
\end{gathered}
$$

\section{Calculate Grey Relational Coefficient}

Grey relational coefficient is the correlation degree between the element of reference sequence and the element of relation sequence, as in (6).

$$
R_{i j}(k)=\frac{M X+\xi \cdot M N}{\Delta_{i}(k)+\xi \cdot M N}
$$

where, $\xi$ is resolution coefficient (usually 0.5);

MX is maximum range;

$\mathrm{MN}$ is minimum range.

\section{E. Calculate Grey Relational Degree}

Grey relational degree is not equal to grey relational coefficient, it is not the correlation degree of two elements but two systems, as in (7).

$$
\gamma_{i j}=\frac{1}{n} \sum_{k=1}^{n} R_{i j}(k)
$$

\section{F. Grey Relational Degree Classification}

The relational degree value is between 0 and 1 , the greater value reflects the stronger correlation between two systems, and vice versa. According to the relational value, the relationship between two systems can be divided into weak correlation, moderate correlation, strong correlation and great correlation (Table 3).

TABLE III. GREY RELATIONAL DEGREE CLASSIFICATION

\begin{tabular}{|c|c|}
\hline Value & Classification \\
\hline $0<\gamma \leq 0.35$ & weak correlation \\
\hline $0.35<\gamma \leq 0.65$ & moderate correlation \\
\hline $0.65<\gamma \leq 0.85$ & strong correlation \\
\hline $0.85<\gamma \leq 1$ & great correlation \\
\hline
\end{tabular}

\section{ANALYSIS OF EXAMPLE}

Hami-Zhengzhou $\pm 800 \mathrm{kV}$ UHVDC transmission project was taken as an example to verify the grey correlation model. The data of each indexes of power sources construction in Henan province were collected in Table 4, and the data of each indexes of Hami-Zhengzhou UHVDC transmission system reliability were collected in Table 5.

TABLE IV. THE DATA OF EVALUATION INDEX SYSTEM OF POWER SOURCES CONSTRUCTION IN HENAN PROVINCE

\begin{tabular}{|c|c|c|c|c|c|c|}
\hline Indexes & $\mathbf{2 0 1 0}$ & $\mathbf{2 0 1 1}$ & $\mathbf{2 0 1 2}$ & $\mathbf{2 0 1 3}$ & $\mathbf{2 0 1 4}$ & $\mathbf{2 0 1 5}$ \\
\hline N-1 pass rate(\%) & 100.0 & 100.0 & 100.0 & 100.0 & 100.0 & 100.0 \\
\hline N-2 pass rate(\%) & 94.6 & 94.6 & 95.0 & 96.0 & 96.0 & 96.5 \\
\hline Short-circuit Curren(kA) & - & - & - & - & 48.21 & 49.59 \\
\hline $\begin{array}{c}\text { The Percentage of Transmission Capacity from } \\
\text { other Provinces(\%) }\end{array}$ & 3.0 & 2.3 & 5.5 & 3.0 & 8.3 & 10.9 \\
\hline $\begin{array}{c}\text { Reactive Power Compensation(Mvar) } \\
\text { Installed Capacity(MW) }\end{array}$ & 28842 & 41131 & 39260 & 52012 & 53229 & 55413 \\
\hline Maximum Load(MW) & 37500 & 43530 & 46710 & 50550 & 52003 & 53500 \\
\hline The Percentage of Conventional Hydropowe(\%) & 5.19 & 4.93 & 4.56 & 4.34 & 4.27 & 3.95 \\
\hline The Percentage of Pumped-storage Power(\%) & 2.02 & 2.48 & 2.29 & 2.18 & 2.13 & 1.96 \\
\hline The Percentage of Thermal Power(\%) & 89.24 & 88.67 & 89.31 & 89.54 & 88.56 & 88.34 \\
\hline $\begin{array}{c}\text { The Percentage of Wind Power(\%) } \\
\text { The Percentage of Photovoltaic Power(\%) }\end{array}$ & 0.10 & 0.20 & 0.27 & 0.44 & 0.70 & 1.35 \\
\hline The Percentage of Renewable Energy(\%) & 7.31 & 7.62 & 7.11 & 7.01 & 7.43 & 7.87 \\
\hline The Weight of Saving Standard Coal (ton) & 3895905 & 4628515 & 5971783 & 4864794 & 4919997 & 5008357 \\
\hline CO $_{2}$ Emission Reduction (ton) & 9614400 & 11422350 & 14737295 & 12005445 & 12141675 & 12359733 \\
\hline SO 2 Emission Reduction (ton) & 289300 & 343702 & 443449 & 361247 & 365346 & 371908 \\
\hline
\end{tabular}


TABLE V. THE DATA OF EVALUATION INDEX SYSTEM OF $\pm 800 \mathrm{KV}$ UHVDC TRANSMISSION SYSTEM

\begin{tabular}{|c|c|c|c|c|c|}
\hline Year & $\begin{array}{c}\text { Energy } \\
\text { Availabil } \\
\text { ity(\%) }\end{array}$ & $\begin{array}{c}\text { Forced } \\
\text { Energy } \\
\text { Unavaila } \\
\text { bility(\%) }\end{array}$ & $\begin{array}{c}\text { Schedule } \\
\text { d Energy } \\
\text { Unavaila } \\
\text { bility(\%) }\end{array}$ & $\begin{array}{c}\text { Monopole } \\
\text { Forced } \\
\text { Outage } \\
\text { Times }\end{array}$ & $\begin{array}{c}\text { Bipolar } \\
\text { Forced } \\
\text { Outage } \\
\text { Times }\end{array}$ \\
\hline 2014 & 94.49 & 0 & 5.51 & 0 & 0 \\
\hline 2015 & 95.53 & 0.14 & 4.33 & 1 & 0 \\
\hline
\end{tabular}

A. Relevancy Analysis of Power Sources Construction and Each Indexes of UHVDC Transmission System

The grey correlation model was used to calculate the relational degree of power sources construction and each indexes of UHVDC transmission system in Table 6.

TABLE VI. THE RELATIONAL DEGREE OF POWER SOURCES CONSTRUCTION AND EACH INDEXES OF UHVDC TRANSMISSION SYSTEM

\begin{tabular}{|c|c|c|c|c|c|}
\hline $\begin{array}{c}\text { Indexes of UHVDC } \\
\text { Transmission } \\
\text { Reliability }\end{array}$ & $Y_{1}$ & $Y_{2}$ & $Y_{3}$ & $Y_{4}$ & $Y_{5}$ \\
\hline Relational Degree & 0.848 & 0.850 & 0.673 & 0.848 & 0.780 \\
\hline
\end{tabular}

In these five indexes, forced energy unavailability (Y2) has a great correlation with power sources construction, and other indexes have a strong correlation with power sources construction.

\section{B. Relevancy Analysis of UHVDC Transmission System and}

Each Indexes of Power Sources Construction

In the same way, the relational degree of UHVDC transmission system and each indexes of power sources construction in Table 7.

TABLE VII. THE RELATIONAL DEGREE OF UHVDC TRANSMISSION SYSTEM AND EACH INDEXES OF POWER SOURCES CONSTRUCTION

\begin{tabular}{|c|c|c|c|c|}
\hline Indexes & $X_{11}$ & $X_{12}$ & $X_{13}$ & $X_{14}$ \\
\hline $\begin{array}{c}\text { Relational } \\
\text { Degree }\end{array}$ & 0.857 & 0.803 & 0.801 & 0.780 \\
\hline Indexes & $X_{15}$ & $X_{21}$ & $X_{22}$ & $X_{23}$ \\
\hline $\begin{array}{c}\text { Relational } \\
\text { Degree }\end{array}$ & 0.890 & 0.678 & 0.679 & 0.871 \\
\hline Indexes & $X_{24}$ & $X_{25}$ & $X_{26}$ & $X_{27}$ \\
\hline $\begin{array}{c}\text { Relational } \\
\text { Degree }\end{array}$ & 0.871 & 0.871 & 0.871 & 0.871 \\
\hline Indexes & $X_{31}$ & $X_{32}$ & $X_{33}$ & $X_{34}$ \\
\hline $\begin{array}{c}\text { Relational } \\
\text { Degree }\end{array}$ & 0.670 & 0.745 & 0.893 & 0.894 \\
\hline
\end{tabular}

In these 16 indexes, $\mathrm{SO}_{2}$ emission reduction (X34), $\mathrm{CO}_{2}$ emission reduction (X33), reactive power compensation (X15), the percentage of conventional hydropower(X23) and $\mathrm{N}-1$ pass rate(X11) have a great correlation with UHVDC transmission system. N-2 pass rate(X12), short-circuit current (X13), the percentage of transmission capacity from other provinces(X14), the weight of saving standard coal(X32), maximum load(X22) and installed capacity(X31) have a strong correlation with UHVDC transmission system.

\section{CONCLUSION}

This paper analyzed the relevancy between power source construction and UHVDC transmission reliability and found the relevancy characteristics of these two system. Frist of all, the paper established the evaluation index system of UHVDC transmission reliability and power sources construction. The evaluation index system of power sources construction comprised 1 first-level index, 3 second-level indexes and 16 third-level indexes. The evaluation index system of UHVDC transmission reliability consisted of 5 indexes. Subsequently, the correlation model was established based on the grey correlation analysis algorithm, and the models were solved by using Matlab software programming. Finally, a province which has landing point of $\pm 800 \mathrm{kV}$ UHVDC transmission engineering was taken for example to conduct a case study. According to evaluation index system and data mining, relational degree value of the UHVDC power transmission and power source construction system were calculated, and the relevancy characteristics between the above two systems were analyzed quantitatively.

\section{ACKNOWLEDGMENT}

This research was supported by North China Electric Power University and State Grid Henan Economic Research Institute.

\section{REFERENCES}

[1] Anonymous, Belarus Might Allow Major Russian Banks Toprovide Loans for NPP Construction-Source[J]. Russia \& CIS Energy Daily, 2011.

[2] Anup Kumar Panda, Nishant Patnaik, Management of Reactive Power Sharing \& Power Quality Improvement with SRF-PAC based UPQC under Unbalanced Source Voltage Condition[J]. Elsevier Journal, 2016.

[3] Ping Zhou, Ying-jin Yao. Grey Correlation Analysis of Factors Influencing Maldistribution in Feeding Device of Copper Flash Smelting[J]. Journal of Central South University, 2012, 19 (7): 938-945.

[4] Matherny M, Eckschlager K, Redundancy and Relevancy of Analytical Results in Multielement Analysis[J. Talanta, 1994, 41 (7):13-18.

[5] Anonymous. Russia-Bulgaria Ink Addition to Nuclear Power Plant Construction Agreement-Source[J]. Russia \& CIS Energy Newswire, 2011.

[6] D.J.Christonfersen, Vancers, H.Elahi, M.G.Bennett. A Survey of the Reliability of HVDC Systems Throughout the World During 1997-1998 CIGRE Report[C], 2000.

[7] Bui L X, Sood V K, Laurin S. Dynamic Interactions Between HVDC Systems Connected to AC Buses in Close Proximity [J], IEEE Transactions on Power Delivery, 2009, 6:223-230.

[8] Thio C V, Davies J B, Kent K L. Commutation Failure in HVDC Transmission Systems [J], IEEE Transactions on Power Delivery, 2006, 11:134-139.

[9] Dr.N.D.Alekseeva, A.V.Bubnova, V.S.Chudny. Reliability Analysis and Comparison of Long Distance HVAC and HVDC Power Transmission Lines[J], IEEE trans on Reliability, 2002, 20:55-61.

[10] H.A.M.Maghraby, R.N.Allan. Application of DC Equivalents to the Reliability Evaluation of Composite Power Systems[J], IEEE trans on Power Systems, 1999, 14:3-9.

[11] Praca A, Eriksson K. Itaipu HVDC Transmission System 10 Years Operational Experience[C], Symposium of Specialists in Electric Operational and Expansion Planning, Recife, Brazil, 1996. 